\title{
ANALISIS KEBUTUHAN ENERGI PROSES PENGGILINGAN KEDELAI DENGAN PENGGERAK MESIN DIESEL DAN MOTOR LISTRIK PADA INDUSTRI TAHU
}

\author{
Sartono Putro \\ Jurusan Teknik Mesin Fakultas Teknik Universitas Muhammadiyah Surakarta \\ Jl. A. Yani Tromol PosI Pabelan Surakarta \\ sartono_putro@ums.ac.id
}

\begin{abstract}
ABSTRAK
Penggunaan teknologi di industri tahu masih mempunyai tingkat keborosan energi yang cukup tinggi Selama ini pada industri tahu dalam proses penggilingan kedelai menggunakan mesin diesel dan motor listrik. Tetapi manajemen energi yang digunakan belum efektif, sehingga perlu diadakan pengkajian ulang tentang konsumsi energinya.

Penelitian ini dilakukan dengan menganalisa kebutuhan bahan bakar, beban oli, daya dan energi untuk proses produksi penggilingan kedelai hingga menjadi sari dari tahu dengan variabel motor listrik dan motor diesel. Sampel didapatkan dari UKM industri tahu dengan 5 UKM menggunakan motor listrik dan 5 UKM menggunakan motor diesel.

Dari penelitian didapatkan bahwa penggunaan motor listrik sebagai penggerak penggiling kedelai lebih murah biaya penggilingannya dibandingkan dengan penggerak mesin diesel. Selain itu, penggunaan mesin penggiling kedelai yang berdaya besar lebih boros konsumsi bahan bakarnya daripada penggerak penggiling kedelai yang yang berdaya kecil.
\end{abstract}

Kata kunci : industri tahu, motor listrik, motor diesel, bahan bakar, daya, beban oli

\section{PENDAHULUAN}

Di Indonesia kebanyakan pelaku bisnis adalah UKM (Usaha Kecil Menengah). Untuk kelangsungan usaha, UKM selayaknya bisa mengantisipasi dan turut peduli dengan resikoresiko dari fenomena krisis energi yang akan terjadi di masa depan. Para pelaku UKM harus mengoptimalkan penggunaan energi yang masih ada.

Masih banyak sekali teknologi yang masih mempunyai tingkat keborosan energi yang cukup tinggi diantaranya adalah industri tahu. Selama ini pada industri tahu dalam proses penggilingan kedelai menggunakan mesin diesel dan motor listrik. Tetapi manajemen energi yang digunakan belum efektif, sehingga perlu diadakan pengkajian ulang tentang konsumsi energinya

\section{TUJUAN PENELITIAN}

1. Mengetahui kebutuhan bahan bakar proses penggilingan kedelai menggunakan mesin diesel.

2. Mengetahui kebutuhan energi pada proses penggilingan kedelai menggunakan motor listrik.

3. Mengetahui perbandingan bahan bakar ( solar dan listrik PLN) yang digunakan pada mesin diesel dan motor listrik. 


\section{BATASAN MASALAH}

1. Penggilingan kedelai menggunakan mesin diesel dan motor listrik

2. Bahan bakar untuk penggilingan kedelai menggunakan mesin diesel dan motor listrik

\section{TINJAUAN PUSTAKA}

Bahan bakar didefinisikan sebagai sumber energi bagi benda kerja. Secara umum untuk mendeteksi adanya besarnya energi yang dimiliki oleh suatu benda kerja yaitu dengan mengukur energi yang dihasilkan benda kerja tersebut. Jika konsumsi bahan bakarnya tinggi maka energi yang dihasilkan oleh benda kerja sangat besar, begitu juga sebaliknya. Jika konsumsi bahan bakarnya rendah maka energi yang dihasilkannya kecil

Penggiling kedelai dibedakan menjadi 2 macam, yaitu :

\section{Mesin diesel [1]}

Mesin diesel adalah motor bakar torak yang terjadi karena proses penyalaan campuran bahan bakar sendiri. Bahan bakar disemprotkan kedalam silinder yang berisi udara dengan temperatur dan tekanan yang tinggi.

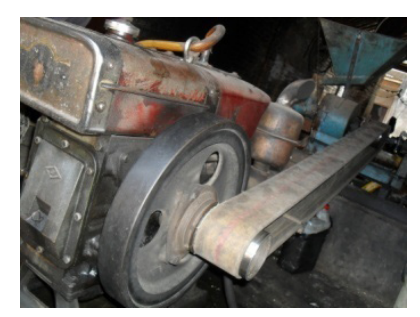

Gambar 1. Mesin diesel

Dengan menggunakan pendekatan konsumsi bahan bakar didapatkan rumus untuk menghitung biaya total penggilingan setiap $\mathrm{kg}$ kedelai :

a. Rumus perhitungan penggunaan bahan bakar tiap kg kedelai

$$
\mathrm{BB}_{\text {tiap kg }}=\frac{\mathrm{BB}_{\text {total }}}{\mathrm{KP}}
$$

Keterangan :

$$
\begin{array}{ll}
\mathrm{BB}_{\text {tiap kg }} & =\text { Bahan bakar (liter } / \mathrm{kg} \text { ) } \\
\mathrm{BB}_{\text {total }} & =\text { Bahan bakar total (liter) } \\
\mathrm{KP} & =\text { Kapasitas produksi (kg) }
\end{array}
$$

Jadi untuk biaya bahan bakar setiap kg penggilingan adalah :

$b \mathrm{BB}_{\text {tiap kg }}=\mathrm{BB}_{\text {tiap kg }} \times$ harga tiap liter solar (Rupiah)

b. Rumus perhitungan beban oli setiap kg kedelai

$$
\mathrm{b}_{\mathrm{oli}}=\frac{\mathrm{Bo}}{\mathrm{t} \times \mathrm{KP}}
$$

Keterangan :

$\mathrm{b}_{\text {oli }} \quad=$ Beban oli (liter $/ \mathrm{kg}$ )

Bo = Kebutuhan oli setiap pergantian berkala (liter)

$\mathrm{KP}=$ kapasitas produksi $(\mathrm{kg})$

$\mathrm{t}=$ waktu penggilingan (jam)

Jadi untuk biaya beban oli setiap kg penggilingan adalah:

$b \mathrm{~b}_{\text {oli }} \quad=\mathrm{b}_{\text {oli }} \times$ harga tiap liter oli (Rupiah) 
c. Rumus biaya total penggilingan setiap kg kedelai

$\mathrm{B}_{\text {total tiap kg }}=b \mathrm{BB}_{\text {tiap kg }}+b \mathrm{~b}_{\text {oli }}$

\section{Keterangan}

$\mathrm{B}_{\text {total tiap kg }}=$ Biaya total penggilingan (Rupiah $/ \mathrm{kg}$ )

$b \mathrm{BB}_{\text {tiap kg }}=$ Bahan bakar setiap kg (Rupiah $/ \mathrm{kg}$ )

$b \mathrm{~b}_{\text {oli }}{ }_{\text {tiap } \mathrm{kg}}=$ Beban oli setiap $\mathrm{kg}$ (Rupiah $/ \mathrm{kg}$ )

\section{Motor listrik $[2,3]$}

Motor listrik bekerja mengubah energi listrik dari sumber listrik PLN menjadi gerakan mekanik.

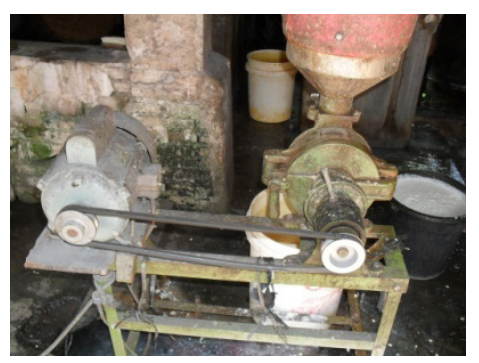

Gambar 2. Motor listrik

Daya listrik adalah ukuran untuk menyatakan banyaknya energi listrik yang telah dipakai setiap detiknya. Dalam menghitung daya yang dihasilkan oleh motor listrik dapat dihitung dengan rumus :

$\mathrm{P}=\mathrm{V} \times \mathrm{I}$

Keterangan :

$\mathrm{P}=$ Daya listrik (Watt)

$\mathrm{V}=$ Tegangan listrik (Volt)

$\mathrm{I}=$ Kuat arus (Ampere)

Energi listrik adalah suatu energi yang dihasilkan sebanding dengan besar tegangan listrik,kuat arus dan waktu. Untuk mencari besarnya energi listrik yang digunakan dapat dihitung dengan menggunakan rumus sebagai berikut.

$\mathrm{W}=\mathrm{V} \times \mathrm{I} \times \mathrm{t}$

Keterangan :

$\mathrm{W}=$ Energi listrik $(\mathrm{KWh})$

$\mathrm{V}=$ Tegangan listrik (Volt)

$\mathrm{I}=$ Arus listrik (Ampere)

$\mathrm{t}$ = Waktu yang digunakan (hour)

Dari rumus diatas dapat dihitung kebutuhan energi setiap kg penggilingan

$\mathrm{W}_{\text {tiap kg }}=\frac{\mathrm{W}}{\mathrm{KP}}$

Keterangan :

$\mathrm{W}_{\text {tiap kg }}=$ Energi listrik $(\mathrm{KWh} / \mathrm{kg})$

$\mathrm{W}^{\text {tiap } \mathrm{kg}}=$ Energi listrik (KWh)

$\mathrm{KP} \quad=$ kapasitas produksi $(\mathrm{kg})$ 


\section{Penelitian Terdahulu}

Murnianto (2008) [4], dalam penelitiannya tentang Pengaruh Putaran Mesin Penggerak Dan Mesin Pengupas Kulit Gabah Yanmar HW 60 AN Terhadap Kualitas Penggilingan Dan Efisiensi Pemakaian Bahan Bakar, yang menyatakan bahwa mesin diesel Ratna R $130 \mathrm{H}$ penggerak mesin penggiling Yanmar HW 60 AN dengan pembebanan putaran penggiling sebesar 1200rpm, didapatkan efisiensi pemakaian bahan bakar pada putaran mesin $1100 \mathrm{rpm}$ sebesar 0,0491 kg/jam hp.

Menurut Wawan Riyanto (2006) [5], dalam penelitiannya tentang Analisa Kekuatan Mesin Pencetak Bakso yang menyatakan bahwa mesin pencetak bakso yang dibuat menggunakan motor listrik sebagai penggerak dengan daya 0,5 HP dan putarannya 1420 rpm dapat menghasilkan 60 biji bakso.

\section{METODE PENELITIAN}

Untuk mempermudah penelitian ini, maka dibuat rangkaian diagram alir penelitian seperti terlihat pada gambar 1 .

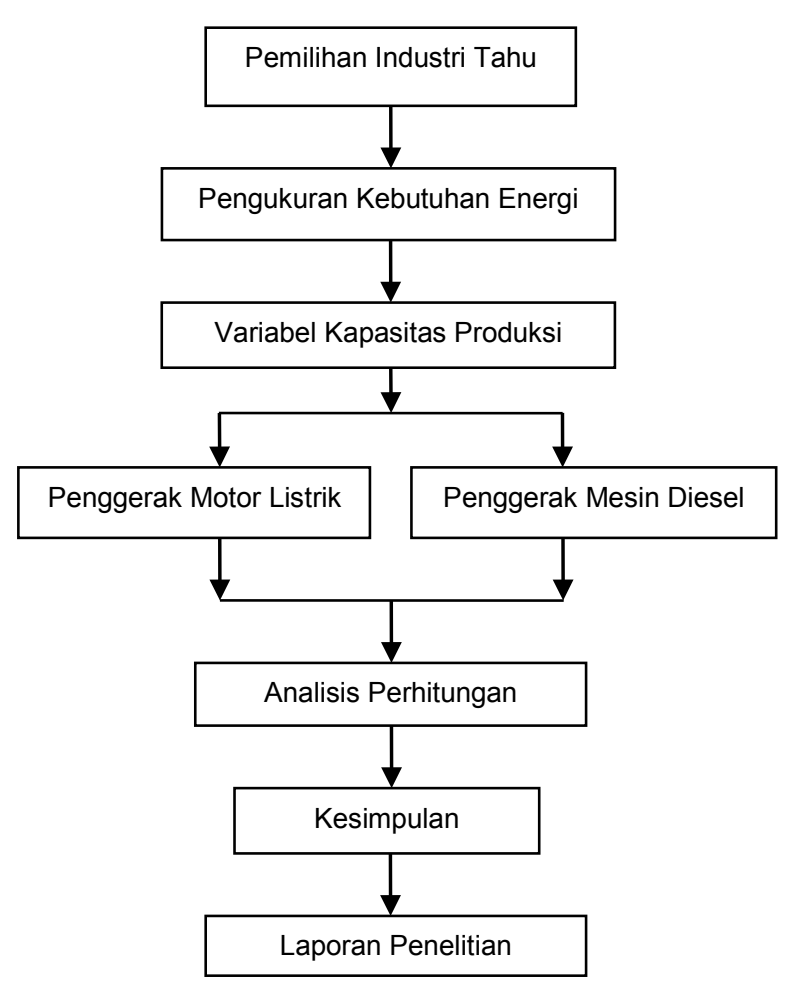

Gambar 3. Bagan alir rancangan penelitian

\section{Bahan dan Alat}

\section{Bahan yang digunakan}

Bahan utama yang digunakan dalam penelitian ini adalah

a. kedelai digunakan untuk membuat bubur kedelai dan seterusnya diproses sehingga menjadi tahu.

b. Air digunakan untuk proses perendaman, penggilingan kedelai

\section{Alat yang digunakan}

a. Hand Tachometer digunakan untuk mengukur putaran mesin 


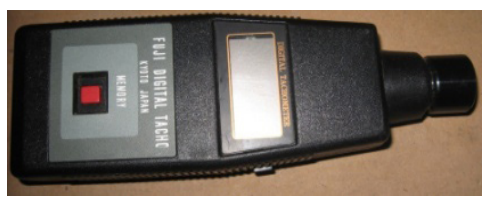

Gambar 4. Hand Tachometer

b. Stopwatch STOP TIMER untuk mengukur waktu penggilingan yang dilakukan oleh mesin penggiling

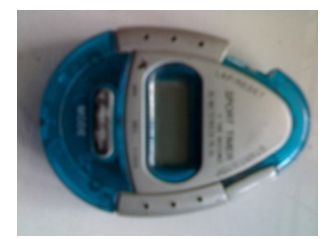

Gambar 5. Stopwatch

c. Timbangan CAMRY dengan kapasitas berat maksimal $120 \mathrm{Kg}$ digunakan untuk mengukur berat kedelai.

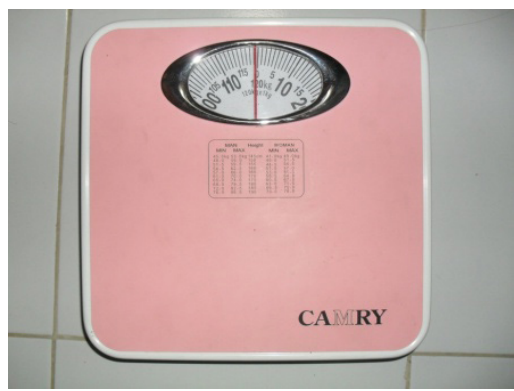

Gambar 6. Timbangan

d. Clampmeter LEM LH 1060 MADE IN CHINA digunakan untuk mengukur tegangan listrik (Volt) dan arus listrik (Amphere) pada motor listrik.

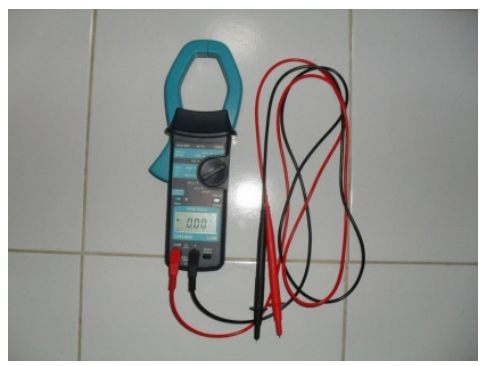

Gambar 7. Clampmeter

\section{Sampel Penelitian}

1. Pabrik yang menggunakan penggerak penggiling dengan mesin diesel

Tabel 1. Jumlah sampel pabrik yang berpenggerak mesin diesel

\begin{tabular}{ccccc}
\hline No & Pemilik & Jenis mesin diesel & Kapasitas produksi & Waktu giling (jam) \\
\hline 1 & Siswanto & Baikuta R180, & $80 \mathrm{~kg}$ & 1,28 \\
& & $8,4 \mathrm{HP}, 2600 \mathrm{rpm}$ & &
\end{tabular}


ISSN: 1411-4348

\begin{tabular}{|c|c|c|c|c|}
\hline 2 & Supangat & $\begin{array}{c}\text { Yanmar TS 60,8 HP, } 2500 \\
\text { rpm }\end{array}$ & $80 \mathrm{~kg}$ & 1,31 \\
\hline 3 & Lestari & $\begin{array}{c}\text { Daifung, } \\
\text { 13,2 HP, } 2000\end{array}$ & $56 \mathrm{~kg}$ & 0,95 \\
\hline 4 & Tukimin & $\begin{array}{c}\text { Amec S 195,12 HP, } 2200 \\
\text { rpm }\end{array}$ & $96 \mathrm{~kg}$ & 1,53 \\
\hline 5 & Heru S. & Yanmar, 8 HP, 2500 rpm & $147 \mathrm{~kg}$ & 1,65 \\
\hline
\end{tabular}

2. Pabrik yang menggunakan penggerak penggiling dengan motor listrik

Tabel 2. Jumlah sampel pabrik yang berpenggerak motor listrik

\begin{tabular}{|c|c|c|c|c|}
\hline No & Pemilik & Jenis motor listrik & Kapasitas produksi & Waktu giling (jam) \\
\hline 1 & Wiyono & $\begin{array}{c}\text { YL } 90 \text { L-4, } 2 \text { HP, } 1440 \\
\text { rpm }\end{array}$ & $89 \mathrm{~kg}$ & 2,38 \\
\hline 2 & Hadi S. & $100 \mathrm{~L} 2-4,1 \mathrm{HP}, 1400 \mathrm{rpm}$ & $140 \mathrm{~kg}$ & 3,43 \\
\hline 3 & Sunarjo & $\begin{array}{c}\text { YC 112-4, } 3 \text { HP, } 1430 \\
\text { rpm }\end{array}$ & $240 \mathrm{~kg}$ & 5,16 \\
\hline 4 & Yuliatun & $\begin{array}{l}\text { JY } 2 \mathrm{~A}-4,1 \mathrm{HP} \\
1420 \mathrm{rpm}\end{array}$ & $80 \mathrm{~kg}$ & 1,83 \\
\hline 5 & Paryanto & JY 2A-4, $1 \mathrm{HP}, 1420 \mathrm{rpm}$ & $64 \mathrm{~kg}$ & 1,37 \\
\hline
\end{tabular}

\section{Instalasi Penelitian}

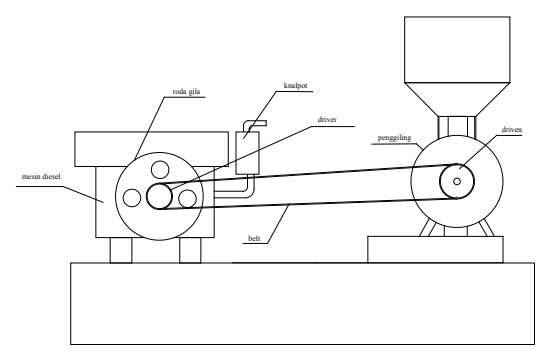

Gambar 8. Penggiling kedelai dengan penggerak mesin diesel

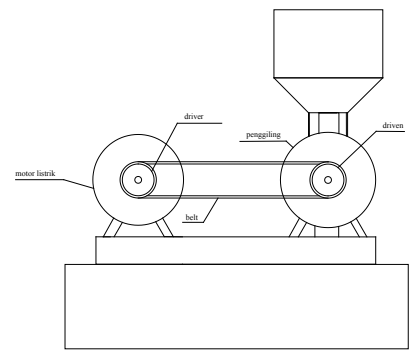

Gambar 9. Penggiling kedelai dengan penggerak mesin diesel

\section{Jalannya Penelitian}

Pertama kali yang harus dilaksanakan adalah mempersiapkan alat-alat, kemudian mengukur jumlah konsumsi bahan bakar mesin diesel dan motor listrik. 


\section{Analisis Data}

Data dianalisis dengan cara menghitung jumlah kebutuhan bahan bakar mesin diesel dan menghitung energi listrik yang dihasilkan motor listrik.

\section{HASIL DAN ANALISIS}

\section{Hasil analisis data}

Tabel 3. Perhitungan total biaya penggilingan tiap kg kedelai

\begin{tabular}{cccc}
\hline Sampel ke- & $\begin{array}{c}\text { Bahan bakar } \\
(\mathbf{R p})\end{array}$ & $\begin{array}{c}\text { Beban biaya oli } \\
(\mathbf{R p})\end{array}$ & $\begin{array}{c}\text { Total biaya penggilingan } \\
(\mathbf{R p})\end{array}$ \\
\hline 1 & 84,14 & 6,25 & 90,39 \\
2 & 78,75 & 7,29 & 86,04 \\
3 & 96,30 & 10,41 & 106,71 \\
4 & 93,60 & 7,09 & 100,09 \\
5 & 76.50 & 5,95 & 82,45 \\
\hline
\end{tabular}

Tabel 4. Harga giling tiap $1 \mathrm{~kg}$ kedelai dalam Rupiah

\begin{tabular}{cccc}
\hline Sampel ke- & $\begin{array}{c}\text { Daya } \\
\text { (watt) }\end{array}$ & $\begin{array}{c}\text { Energi } \\
\text { (KWh) }\end{array}$ & $\begin{array}{c}\text { Harga energi tiap kg } \\
\text { (Rp) }\end{array}$ \\
\hline 1 & 1379 & 3,28 & 33,76 \\
2 & 696,5 & 2,39 & 17,18 \\
3 & 2068,5 & 10.67 & 44,88 \\
4 & 686 & 1,25 & 15,47 \\
5 & 686 & 0,93 & 14,76 \\
\hline
\end{tabular}

\section{Pembahasan}

a. Mesin diesel

1. Pembahasan konsumsi bahan bakar untuk proses penggilingan setiap kg kedelai

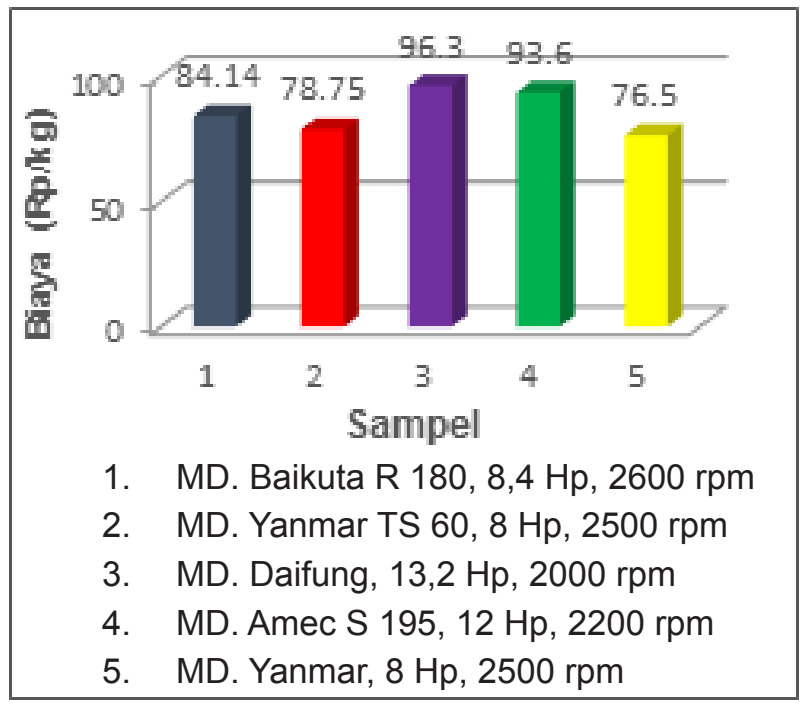

Gambar 10. Konsumsi bahan bakar pada penggilingan

Dari gambar diatas, menunjukkan bahwa konsumsi bahan bakar penggilingan kedelai yang paling rendah adalah sampel 5 dengan biaya $\mathrm{Rp} 76,5$ untuk tiap kg kedelai. Dan konsumsi bahan bakar penggilingan kedelai yang paling tinggi ditunjukkan pada 
ISSN: 1411-4348

sampel 3 dengan harga Rp 93,3 untuk tiap kg kedelai.

2. Pembahasan beban oli mesin untuk proses penggilingan setiap kg kedelai

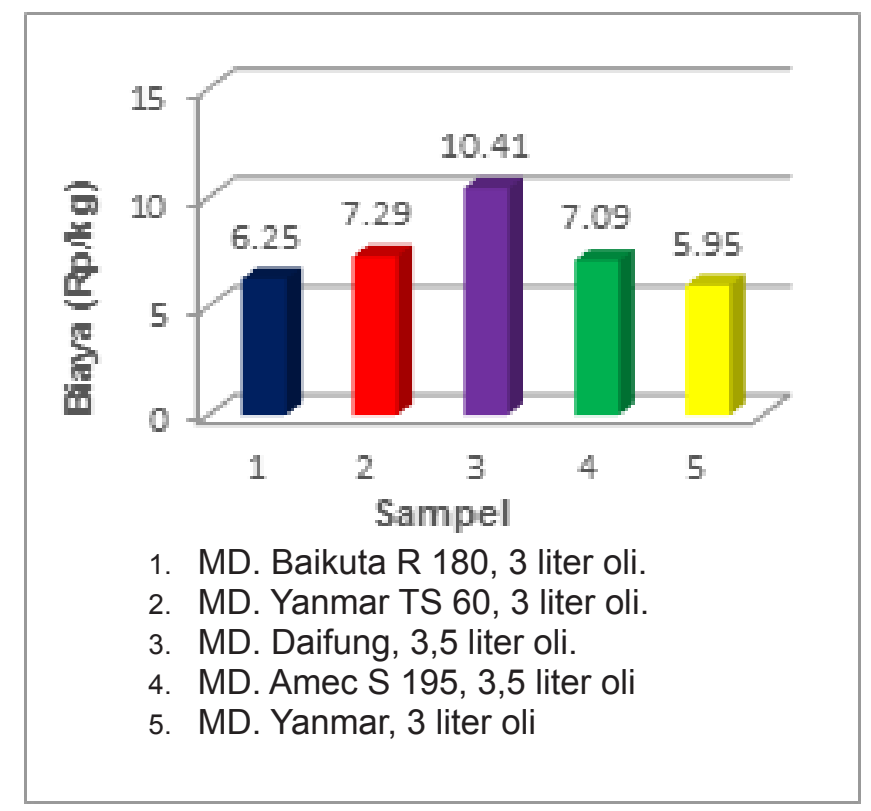

Gambar 11. Biaya pergantian oli untuk setiap kg penggilingan

Dari gambar diatas, menunjukkan bahwa biaya pergantian oli mesin diesel yang paling rendah adalah sampel 5 dengan biaya $\mathrm{Rp}$ 5,95 untuk tiap kg kedelai. Dan biaya pergantian oli yang paling tinggi pada sampel 3 dengan biaya penggilingan $\mathrm{Rp} 10,41$ untuk tiap kg kedelai.

3. Pembahasan biaya penggilingan yang digunakan untuk menggiling setiap kg kedelai

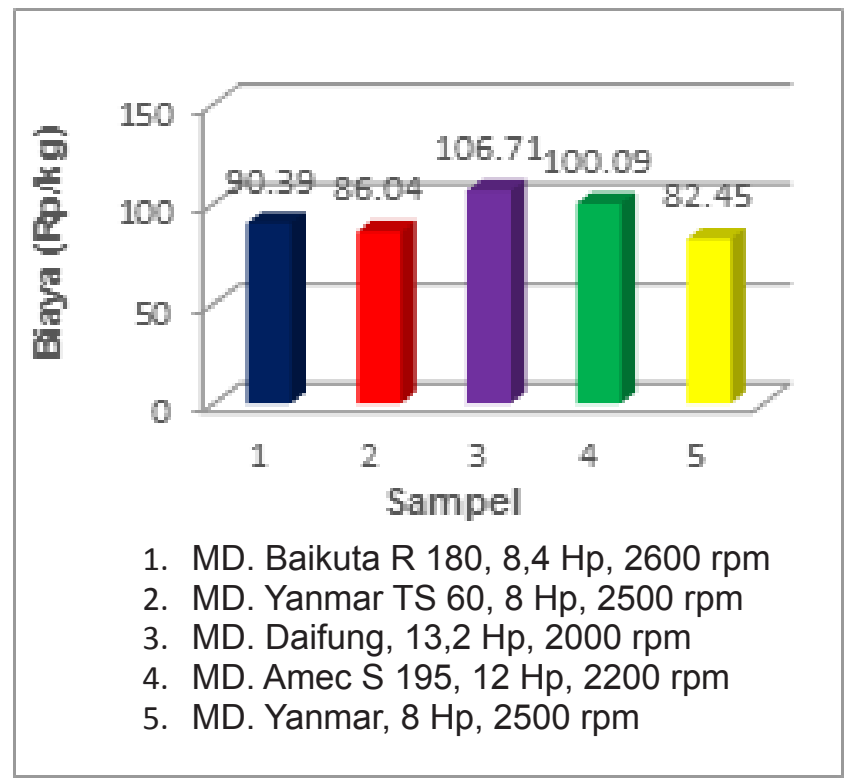

Gambar 12. Biaya total penggilingan untuk setiap kg kedelai

Dari gambar diatas, menunjukkan bahwa biaya penggilingan kedelai yang mencakup biaya bahan bakar dan biaya oli tiap kg yang paling hemat adalah sampel 3 dengan biaya 
total $\mathrm{Rp} 82,45$, dan yang paling banyak mengeluarkan biaya untuk penggilingan kedelai ditunjukkan pada sampel 3 dengan biaya total Rp 106,71.

b. Motor listrik

1. Pembahasan daya yang dihasilkan motor listrik.

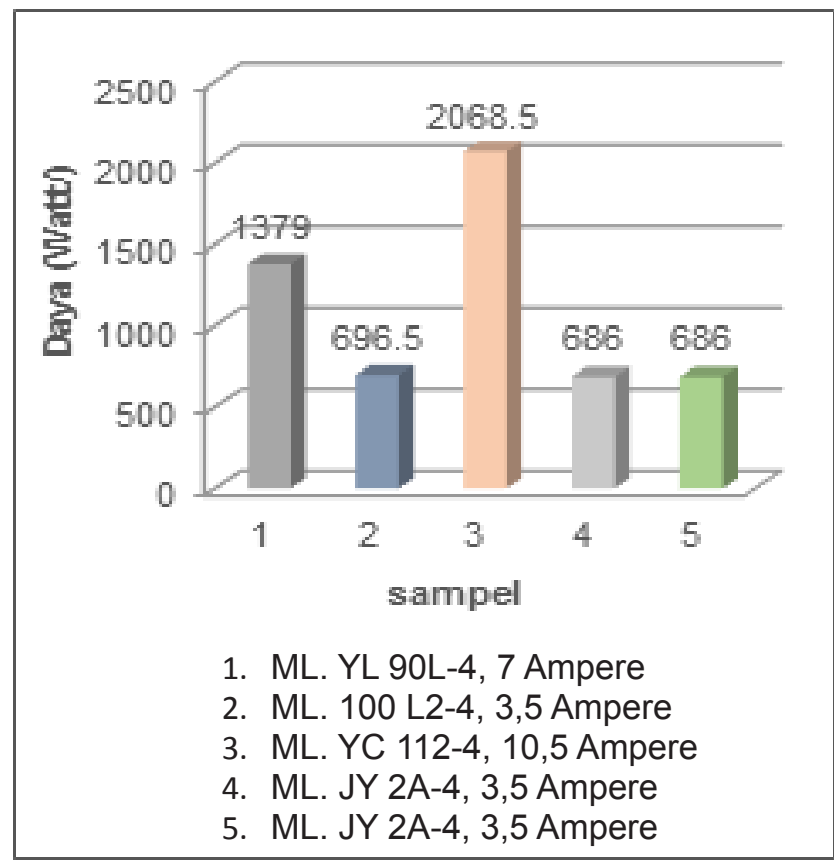

Gambar 13. Besar daya yang dihasilkan motor listrik penggiling kedelai.

Dari gambar diatas, menunjukkan bahwa pemakaian motor listrik yang berdaya kecil adalah sampel 4 dan sampel 5 dengan daya 686 watt. Dan pemakaian daya yang paling besar ditunjukkan pada sampel 3 dengan daya 2068,5 watt.

2. Pembahasan energi yang dihasilkan motor listrik.

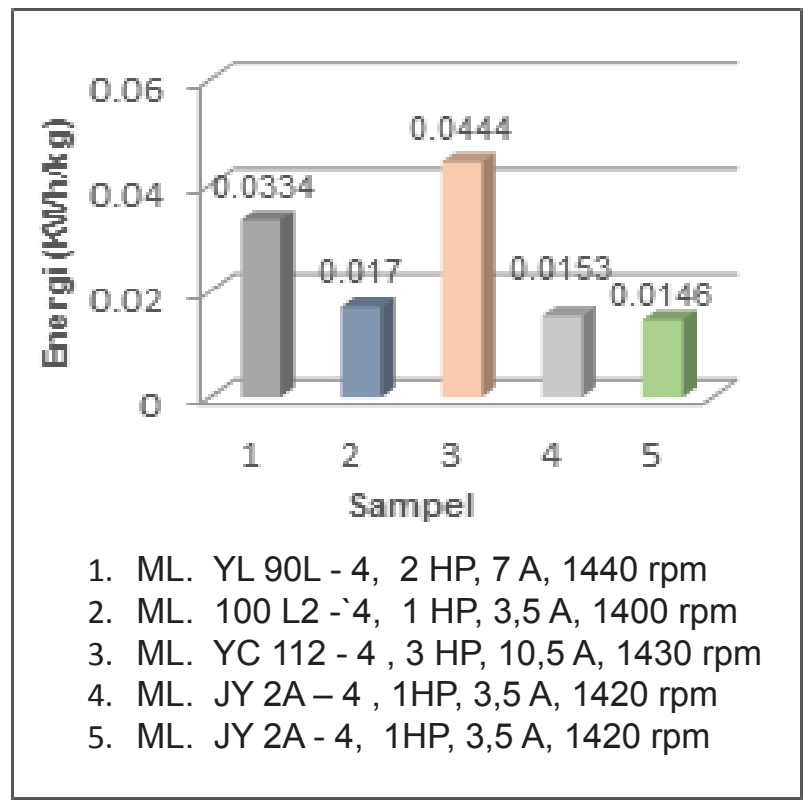

Gambar 14. Besar energi untuk setiap kg kedelai yang dihasilkan motor listrik penggiling kedelai. 
Dari gambar sebelumnya tentang daya motor listrik, didapatkan data energi untuk penggilingan tiap kg kedelai dengan menggunakan motor listrik. Maka pada gambar diatas didapat energi yang paling kecil untuk penggilingan kedelai adalah sampel 5 dengan besar energi $0.0146 \mathrm{KWh}$. Dan untuk enrgi yang paling besar adalah sampel 3 dengan besar energi $0,0444 \mathrm{KWh}$.

3. Pembahasan biaya penggilingan yang digunakan untuk menggiling setiap $\mathrm{kg}$ kedelai.

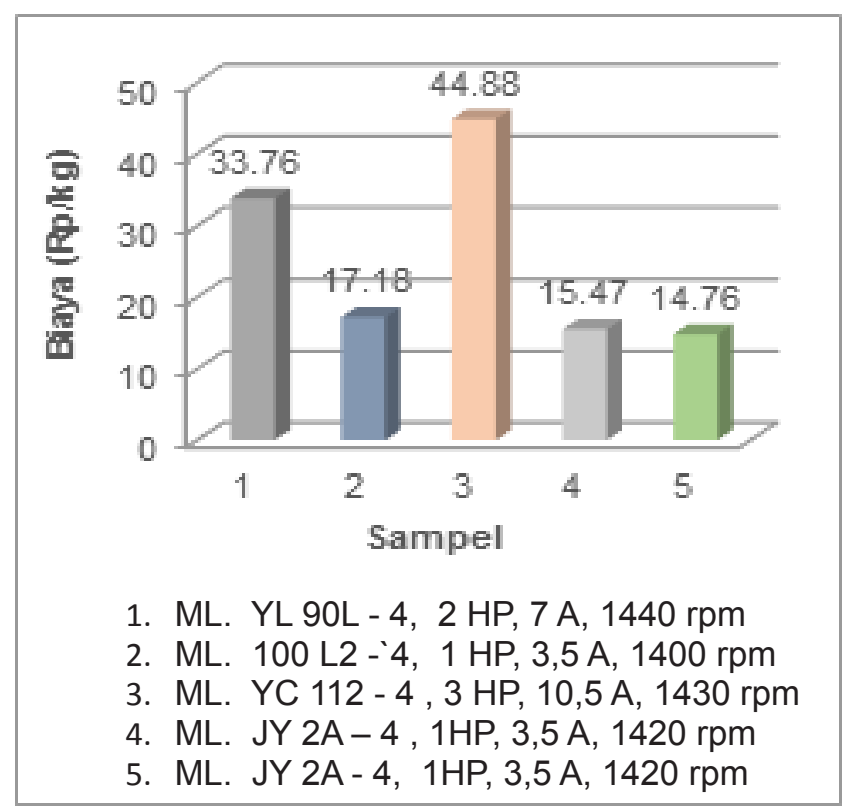

Gambar 15. Tingkat biaya penggilingan tiap kg kedelai dengan motor listrik.

Dari gambar diatas, menunjukkan bahwa biaya penggilingan untuk tiap kg kedelai dengan motor listrik yang paling hemat adalah sampel 5 dengan biaya Rp14,76 per $\mathrm{kg}$ kedelai. Dan biaya penggilingan yang paling boros adalah sampel 3 dengan biaya Rp 44,88 tiap kg kedelai.

c. Perbandingan biaya penggilingan mesin diesel dan motor listrik

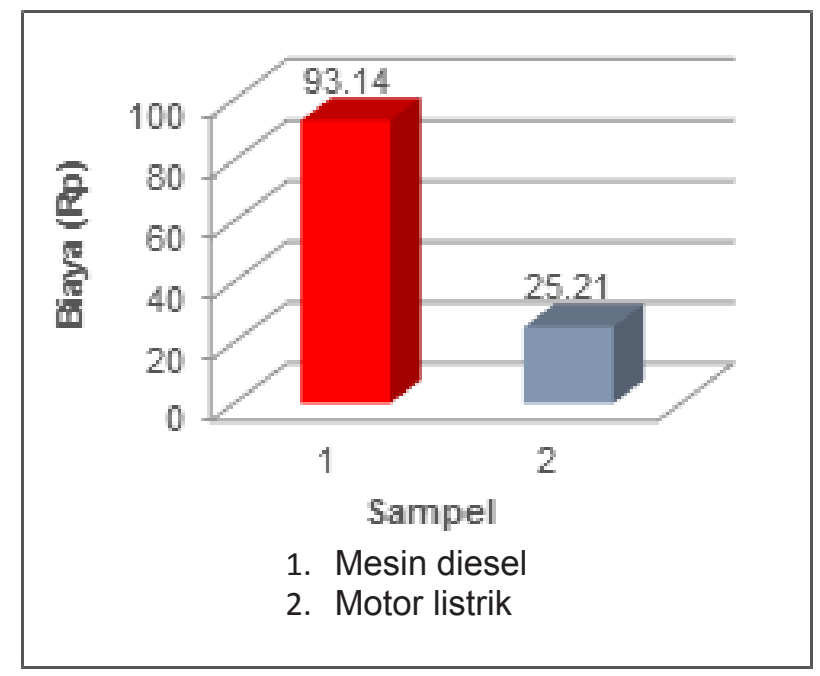

Gambar 10. Perbandingan biaya penggilingan setiap kg kedelai antara mesin diesel dengan motor listrik 
Dari gambar diatas dapat diketahui bahwa konsumsi energi proses penggilingan kedelai yang paling hemat adalah menggunakan motor listrik dibandingkan dengan mesin diesel.

\section{PENUTUP}

\section{Kesimpulan}

a. Penggunaan motor listrik sebagai penggerak penggiling kedelai lebih murah biaya penggilingannya dibandingkan dengan penggerak mesin diesel.

b. Penggunaan mesin penggiling kedelai yang berdaya besar lebih boros konsumsi bahan bakarnya daripada penggerak penggiling kedelai yang yang berdaya kecil.

\section{Saran}

a. Untuk perencanaan sebuah penggiling kedelai terlebih dahulu memahami tentang prinsip dari konversi energi mekanik.

b. Dalam merencanakan sebuah penggiling kedelai lebih baik memakai motor listrik yang berdaya kecil agar biaya penggilingannya lebih murah.

\section{DAFTAR PUSTAKA}

[1] Arismunandar W, 2004, Motor Diesel Putaran Tinggi. Pradnya Paramita: Jakarta.

[2] Sidik, 2008, “Energi Dan Daya Listrik” 11 november 2008. Diakses 04 Februari 2010, dari http://wahab.blog.dada.net.

[3] Zuhal, 1995, Dasar Teknik Tenaga Listrik Dan Elektronika Daya, Gramedia Pustaka Utama: Jakarta.

[4] Murnianto, 2008, Pengaruh Putaran Mesin Penggerak Dan Mesin Pengupas Kulit Gabah Yanmar HW 60 AN Terhadap Kualitas Penggilingan Dan Efisiensi Pemakaian Bahan Bakar, Tugas Akhir S1 Jurusan Teknik Mesin, Universitas Muhammadiyah Surakarta: Surakarta.

[5] Riyanto W, 2006, Analisa Kekuatan Mesin Pencetak Bakso, Tugas Akhir S1 Jurusan Teknik Mesin, Universitas Muhammadiyah Surakarta: Surakarta. 